\title{
Analysis of Going Concern Audit Opinion Receiving Trends at Property Companies in Indonesia
}

\author{
R. M. Arnaldo Simbolon Dr. Wahyu Ari Andriyanto Samin \\ Universitas Pembangunan Nasional "Veteran" Jakarta, Indonesia, PO box 12450, Jakarta, Indonesia
}

\begin{abstract}
Responsibilities of auditors currently do not only focus on assessing the fairness of financial statements and detecting fraud, but also assess the company's ability to maintain its survival. This is due to the demands of the shareholders to the auditor to provide early warning about the prospects of a company as consideration before deciding on an investment decision . This study aims to determine the effect of financial distress, debt default, and company size on going concern audit opinion. This research uses quantitative research methods. This research data uses secondary data through documentation and literature studies. The population in this study are property companies listed on the Indonesia Stock Exchange in 2016 - 2018. The sample in this study amounted to 171 observational data from 57 companies selected using the purposive sampling method The analysis used in this study is logistic regression analysis at the 5\% significance level. The results of hypothesis testing show that financial distress and company size do not affect going concern audit opinion, while debt default has a significant positive effect on going concern audit opinion .
\end{abstract}

Keywords: Going concern Audit Opinion, Financial distress, Debt default, Firm Size

DOI: $10.7176 /$ RJFA/11-18-03

Publication date:September $30^{\text {th }} 2020$

\section{Introduction}

One form of management accountability to stakeholders, especially shareholders, is financial reports. Financial statements provide information about the state of a company that is used as the main consideration in making decisions. In order to make reliable financial reports, an auditor is needed who acts as a third person in bridging the interests of users and providers of financial statements.

Auditors provide assurance services for the output of a company in ensuring that everything the company does is in accordance with accounting standards and provides information in accordance with actual conditions (Hartono \& Dewi, 2018). In providing their services, auditors assess the fairness of a company's financial statements in the form of an audit opinion contained in the audit report".

Opinion on financial statements is a very important consideration for investors in their decision to invest so that the role of auditors is needed in providing information. "In providing an audit opinion, there are many factors that influence the auditor in assessing the fairness of a financial report". One of these factors is the potential for the company's business continuity or going concern. Going concern is one of the auditors' considerations in giving their opinion.

Clarkson (1994) in Januarti \& Fitrianisari (2008) conducted research on investors' reactions to audit opinions which contain information about a company's going concern. Knowing the company's financial condition, especially regarding its viability, is very necessary when investors will invest in a company. Accuracy of auditors in considering the viability of the company is needed so that the audit opinion can produce useful information and serve as a warning for investors to make investment decisions.

"The going concern of the company is not the responsibility of the auditor, but the auditor is responsible for providing an opinion regarding the possibility of a potential company bankruptcy". "If the auditor concludes that there is substantial doubt about the ability of the company to continue its business, an opinion with an emphasis paragraph should be published".

Clarkson (1994) in Januarti \& Fitrianisari (2008) conducted research on investors' reactions to audit opinions which contain information about a company's going concern. Knowing the company's financial condition, especially regarding its viability, is very necessary when investors will invest in a company. Accuracy of auditors in considering the viability of the company is needed so that the audit opinion can produce useful information and serve as a warning for investors to make investment decisions.

"The going concern of the company is not the responsibility of the auditor, but the auditor is responsible for providing an opinion regarding the possibility of a potential company bankruptcy". "If the auditor concludes that there is substantial doubt about the ability of the company to continue its business, an opinion with an emphasis paragraph should be published.

"One of the factors that are considered by auditors in assessing the viability of the company is the status of debt default". "Debt default is the failure of a debtor (company) to fulfill its obligations (Susanto 2009)". "The first thing an auditor will do to determine the financial health condition of a company is to examine the company's debt". 
"A company that is unable to fulfill its obligations at maturity is considered to be in a state of debt default, so it is very likely that it will receive a going concern audit opinion because it will disrupt operational activities which can threaten the company's survival (Kesumojati et al., 2017) .

Another financial factor that describes the health level of a company is financial distress, which refers to a company's financial condition and performance that shows a decline prior to bankruptcy or liquidation (Platt \& Platt, 2002) . Kesumojati et al. (2017) in their research explains that companies in financial distress are likely to receive a going concern audit opinion because they indicate doubts about the continuity of their business so that they are likely to go bankrupt .

Problems arise when there are many wrong opinion made by auditors regarding going concern audit opinion (Kartika, 2012). Going concern audit opinion is bad news for companies, especially users of financial statements. The going concern assumption in auditing means that there is doubt about the continuity of the business, that is, the company is in a difficult stage to operate or the worst thing is that there are signs of bankruptcy.

Apart from debt default and financial distress, another factor that affects is company size. Diyanti (2010) states that company size affects the acceptance of going concern opinion. The bigger the size of a company, the company is considered more capable of ensuring the survival of the company.

A case regarding a going concern recently occurred in Indonesia. It is known that an investment company in the property sector PT Hanson International Tbk received a going concern opinion from EY-affiliated Purwanto Sungkoro and Surja Public Accounting Firm because the consolidated financial statements contained a large accumulated deficit. This indicates a material uncertainty that could cause significant doubt about the group's ability to pay its debt and maintain its going concern.

From the phenomenon that has been described, it can be concluded that giving an opinion from the auditor is very important. However, it can be proven that the fact that there are still auditors who are unable to provide early warning in the form of going concern audit opinion on companies that have problems with the company's ability to maintain its survival . An error in providing an audit opinion will have fatal consequences for users of financial statements . The users of financial statements will certainly take wrong actions or decisions as a result of these mistakes . This means requiring auditors to be more aware of potential matters that may interfere with the survival of an entity.

The problem in this study is whether financial distress, debt default, and company size affect going-concern audit opinion. While the purpose of this study is to determine what factors allow property companies in Indonesia to receive going concern audit opinion on their financial reports. The results of this study are expected to be a company consideration regarding the importance of factors that influence going concern audit, for investors it is expected to provide information about the prospects of a company in investing, and for Public Accounting Firms and Public Accountants it is expected to be a reference in audit considerations to assess the viability of the company

\section{Literature Review}

\subsection{Agency Theory}

The theory related to this research is agency theory. Jensen \& Meckling (1976) defines agency theory as a contractual relationship between one or more parties called the principal as the owner which involves another party called the agent as management to carry out a management on behalf of the principal which involves delegation in decision making to the agent .

Based on agency theory, it is stated that the relationship between the principal and agent leads to an unbalanced information condition. This happens because the agent has more information about the company than the principal. Auditing plays an important role in the principal and agent relationship.

To reduce information asymmetry, an independent third party is needed as a mediator in the relationship between the principal and agent, namely the external auditor as a party capable of bridging the interests of the principal and agent. Among the duties of the auditors are to examine and provide an opinion on the fairness of financial statements. Financial reports prepared by management require checks to be more reliable and reliable.

In relation to going concern opinion, in addition to assessing the fairness of financial statements prepared by management, an auditor is also responsible for considering and assessing the viability of the company .

\subsection{Signal Theory}

Signal theory suggests how managers in an entity have the incentive to provide information to external parties in order to reduce information asymmetry. Providing information or signals is carried out by managers in order to reduce information asymmetry (Apriyani et al., 2018) .

From the above understanding, it can be concluded that signal theory explains how the failure signal and success of the agent should be conveyed to the principal. These signals or information can be presented through the company's financial statements. The impetus for providing signals arises because of the information asymmetry between the agent and the principal, where the agent has more information about the company than the principal. 
The information presented by the company can be in the form of good news or bad news. Related to a going concern opinion issued by an independent auditor, this opinion will provide a signal for creditors and investors to help determine credit or investment decisions.

O'Reilly (2010) explains that going concern audit opinion is considered bad news for users of financial statements. The bad news in question is a negative signal about doubts about the continuity of the company's business, this signal is used as an early warning for investment or funding decisions .

\subsection{Going Concern Audit Opinion}

Going concern audit opinion according to Rahayu \& Pratiwi (2011) is an opinion in the explanatory paragraph regarding the auditor's consideration that there is an indication of a company's failure in maintaining its survival in carrying out operational activities in the future .

The auditor's responsibility in assessing the sustainability of a company is contained in Audit Standard 570 (2013), namely :

- To obtain sufficient audit evidence regarding the appropriateness of the use of the going concern assumption by management in preparing the financial statements .

- To conclude, based on the audit evidence obtained, whether there is a material uncertainty regarding events or conditions that give rise to doubt as to the entity's ability to maintain as a going concern; and .

- To determine the impact on the audit report .

\subsection{Financial Distress}

Platt \& Platt (2002) define financial distress as a stage of decline in financial conditions that occur before bankruptcy or liquidation occurs .

Fanny \& Saputra (2005) explain that companies experiencing financial distress indicate doubts in maintaining business continuity and are threatened with bankruptcy so that they are likely to receive a going concern audit opinion. This is because in providing this opinion, the auditor will certainly pay attention to the financial condition of a company. A company that does not experience financial difficulties is unlikely to receive a going concern audit opinion . Conversely, if a company is indicated to have financial difficulties, it is likely that it will receive a going concern audit opinion .

H1 : Financial distress has a significant effect on going concern audit opinion

\subsection{Debt Default}

Default debt or failure to pay debt is the definition of negligence or failure of a company in its principal debt and interest at maturity (Praptitorini \& Januarti, 2011) .

Debt status is a factor that will be carried out by auditors for the first time because it refers to Audit Standard 570 (2013), the company's failure to fulfill its obligations is one of the indicators most widely used by auditors in assessing the company's survival due to disruption of the company's operational activities . This concludes that the greater the inability of the company to fulfill its obligations, the more likely the company will receive a going concern audit opinion .

H2 : Debt default has a significant effect on going-concern audit opinion.

\subsection{Company Size}

According to Brigham \& Houston (2010:4) company size is the size of a company that is shown or valued by total assets, total sales, total profits, tax expenses and others .

The size of the company determines whether the company can carry on its business life for a long time or not . Usually, large companies will be more able to maintain the viability of their business than small companies that can be said to be new, and are less biased in maintaining the viability of their businesses . H3 : Company size has a significant effect on going concern audit opinion.

\section{Research Methodology}

3.1 Population and Sample

The population in this study are all property companies listed on the Indonesia Stock Exchange for the period 2016 - 2018 . Property companies were chosen because of the impact of the prolonged depreciation of the rupiah, the property sector is vulnerable because many development companies have large amounts of debt in US dollars. Although the debt burden has increased, some developers do not have sufficient funds to pay off their obligations this year and do not have hedging agreements. Based on the calculations of the international rating agency Fitch Rating, the portion of debt denominated in dollars for each developer company listed on the Indonesia Stock Exchange (IDX) is about $50 \%$ of the total debt each. This proportion is large because debt instruments denominated in dollars attract a wider investor base and have lower interest rates than local bonds or bank credit. However, bonds denominated in foreign currency (forex) risk being exposed to fluctuations in the rupiah exchange rate. This 
is what is happening now. Development companies actually have a large profit margin. However, property demand is currently sluggish. Consumers with purchasing power also put the brakes on spending while monitoring economic and political developments. Therefore, Fitch Rating predicts presales sales will continue to fall. In the end, this condition puts pressure on the development company's ability to pay off its obligations.

In this study, the sampling technique used was nonprobability sampling with purposive sampling technique . According to Sugiyono (2016: 85), purposive sampling is a technique of sampling data sources with certain considerations . The reason for using purposive sampling technique is because not all samples have criteria that match the phenomenon under study. Therefore, the researcher chooses purposive sampling technique which determines certain considerations or criteria that must be met by the samples used in this study. The criteria used as the sample of this study are:

- Registered as a property company on the Indonesia Stock Exchange and did not experience delisting during the 2016 - 2018 period.

- The company reports and publishes annual financial reports for 2016 - 2018.

- The company publishes annual financial reports that provide all the data needed for the research.

3.2 Variable Measurement

3.2.1 Going Concern Audit Opinion

This variable is measured using a dummy scale, which is measured using code 1 if the company accepts going concern audit opinion (GCAO) and code 0 if it does not accept non going concern opinion (NGCAO) . Going concern opinion is contained in the emphasis paragraph in the independent auditor's report .

3.2.2 Financial Distress

In this study the financial distress variable was measured using the Altman bankruptcy modification revision prediction model.

The equation formula is as follows:

$$
\mathrm{Z}=6,56 \mathrm{X} 1+3,26 \mathrm{X} 2+6,72 \mathrm{X} 3+1,054 \mathrm{X} 4
$$

Note:

$\mathrm{X} 1=$ working capital / total asset

$\mathrm{X} 2=$ retained earnings / total asset

$\mathrm{X} 3=$ earnings before interest and taxes/total asset

$\mathrm{X} 4=$ market value of equity / book value of total debt

The criteria for this model equation are if:

- Z"Score $<1,1$ then the company is categorized as a bankrupt company.

- $1,1<\mathrm{Z}$ " Score $<2,6$ then the company is a gray area company (can not be determined healthy or bankrupt).

- Z'Score $>2,6$ then the company is categorized as a healthy company.

Code 1 is used for companies experiencing financial difficulties while code 0 is used for companies that are not experiencing financial difficulties . For companies that are included in the gray area, the value of $1.1>1.85$ is considered to tend towards experiencing financial difficulties and the value of $1.86<2.6$ is considered to tend towards not experiencing financial difficulties resulting in the following criteria:

- Z Z Score $<1.85$ is considered as the company experiencing financial difficulties.

- 1.85 is considered as the company is not experiencing financial difficulties.

3.2.3 Debt Default

The debt default variable in this study is measured using a dummy scale to show whether the company is a company with a debt default or non-debt default status. The value 1 is used for companies with the default ldebt status, the value 0 is used for non debt default status. The debt default status is disclosed in the notes to the financial statements or in the independent audit opinion report .

In Mada \& Laksito's (2013) research, to find out whether a company is included in the debt default or non-debt default condition, it can be seen if one of the following criteria is fulfilled, namely:

- The company's inability or negligence in paying principal or interest payable.

- There is a violation of the debt agreement by the company, or the company is unable to meet the requirements of the debt agreement

- The company is in the process of negotiating a debt restructuring that is due during the financial reporting period.

3.2.4 Company Size

One measure of the size of the company is by looking at the company's total assets. Total assets are used as the size of the company because of the total assets owned by the company, it can be seen how the company's business continuity in the future. The higher the total assets owned by the company, then the company is considered a large company so that it is able to maintain its business continuity so that the company is likely to receive a non going concern audit opinion. Santosa and Wedari (2007) found that size (company size) has an effect on going 
concern opinion, while Januarti and Fitrianasari (2008) found empirical evidence that the size of the client company has no effect on the going concern opinion issued by the auditor .

$$
\text { Company Size }=\text { Ln (total asset). }
$$

\section{Data Analysis}

The analysis technique used is logistic regression analysis, then the collected data is processed using statistical analysis tools in the form of SPSS (Statistical Package for Social Science) software version 24.0 for Windows . The logistic regression analysis stages are model feasibility test, overall model test, determination coefficient test, classification table, multicollinearity test, and partial hypothesis testing .

The regression model developed in this study is as follows:

with:

$$
\operatorname{Ln} \frac{G c}{1-G c}=\alpha+\beta 1 D E B T+\beta 2 B A N K R U P T+\beta 3 S I Z E+\varepsilon
$$

$$
\begin{gathered}
G C=\frac{1}{1+e(\alpha+\beta 1 D E B T+\beta 2 B A N K R U P T+\beta 3 S I Z E} ; \text { or } \\
\begin{aligned}
\text { Ln } \frac{G C}{1-G C} \quad=e^{\alpha+\beta 1 D E B T+\beta 2 B A N K R U P T+\beta 3 \text { SIZE }+\varepsilon} \\
=e^{a} x e^{\beta 1 D E B T} x e^{\beta 2 B A N K R U P T} x e^{\beta 3 S I Z E}
\end{aligned}
\end{gathered}
$$

Note:

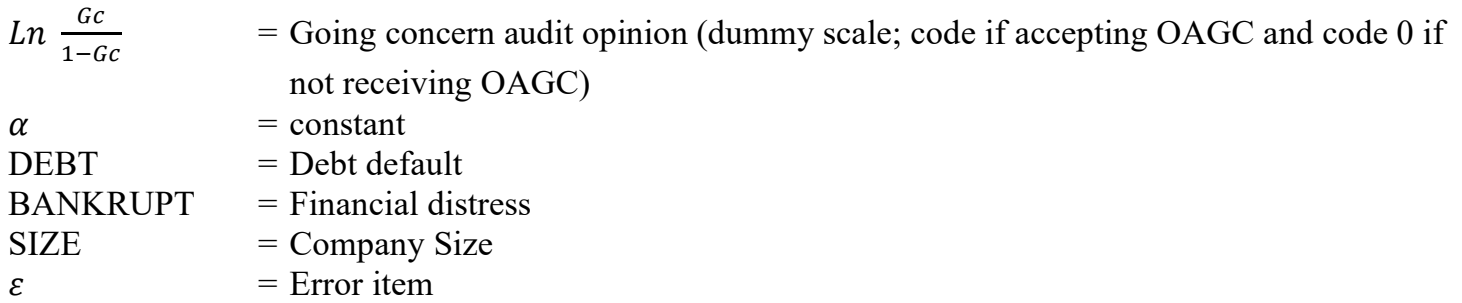

\section{Results and Discussion}

\subsection{Data Description}

This study uses property companies listed on the Indonesia Stock Exchange from 2016 to 2018 as research samples . Based on the sample selection process using the purposive sampling method that has been carried out, 57 companies were obtained with 171 data . The dependent variable of this study is a going concern audit opinion. Financial distress, debt default and company size are independent variables in this study .

The research data uses audited financial reports and company annual reports. The results of the research data tabulation are in the appendix.

\begin{tabular}{lrrrrr}
\hline \multicolumn{7}{c}{ Descriptive Statistics } & & \\
\hline & N & \multicolumn{1}{c}{ Minimum } & Maximum & Mean & \multicolumn{1}{c}{ Std. Deviation } \\
\hline OAGC & 171 & 0 & 1 &, 06 &, 246 \\
\hline BANKRUPT & 171 & 0 & 1 &, 19 &, 391 \\
\hline DEBT & 171 & 0 & 1 &, 09 &, 284 \\
\hline SIZE & 171 & 10,88 & 14,09 & 12,7083 &, 61569 \\
\hline Valid N (listwise) & 171 & & & & \\
\hline
\end{tabular}

Table 1 shows the descriptive statistics of each research variable. The minimum value of financial distress indicates the company's financial condition is 0 . The maximum value of financial distress indicates that the company's financial condition is 1 . The average (mean) financial distress indicates the company's financial condition is 0.19 . Meanwhile, the standard deviation of financial distress is 0.391 . The average value (mean) is smaller than the standard deviation of $0.19<0.391$ which indicates that financial distress has low distribution and fluctuation .

The minimum debt default value indicates the company's failure to pay its debt is 0 . The maximum debt default value indicates the company's failure to pay its debts is 1 . The average (mean) debt default indicates the company's failure to pay its debt is 0.09 . Meanwhile, the standard deviation of debt default was 0.284 . The average value (mean) which is smaller than the standard deviation of $0.09<0.284$ indicates that debt default has low distribution and fluctuation.

The minimum value of company size shows that the size of the company is 10.88 from PT. MTSM with total assets of IDR 75,129,492,493. The maximum value of company size is 14.09 from PT WSKT in 2018 with total assets of IDR 124,391,581,623,636, -. The average (mean) size of the company was 12.7083. Meanwhile, the 
standard deviation of the company size is 0.61569 . The average (mean) value that is greater than the standard deviation of $12.7083>0.61569$ indicates that the size of the company has high distribution and fluctuation.

The minimum value of going concern audit opinion is 0 . The maximum value of going concern audit opinion is 1 . The average (mean) going concern audit opinion is 0.06 . Meanwhile, the standard deviation of going concern audit opinion is 0.246 . The average value (mean) is smaller than the standard deviation of $0.06<0.246$ indicating that the going-concern audit opinion has low distribution and fluctuation.

\section{BANKRUPT}

\begin{tabular}{rrrrrr} 
& & Frequency & Percent & Valid Percent & Cumulative Percent \\
\hline \multirow{3}{*}{ Valid } & 0 & 139 & 81,3 & 81,3 & 81,3 \\
\cline { 2 - 6 } & 1 & 32 & 18,7 & 18,7 & 100,0 \\
\cline { 2 - 6 } & Total & 171 & 100,0 & 100,0 & \\
\hline
\end{tabular}

Figure 2. Financial distress frequency

Based on table 2, it is known that in this study the sample companies that did not experience financial difficulties were $81.3 \%$ with a total of 139 companies, while the sample companies experiencing financial difficulties were $18.7 \%$ with a total of 32 companies. It can be concluded that in this study, most of the property companies in the study sample did not experience financial difficulties or the companies were in sound financial condition. The company that has the lowest Z-Score or the worst level of financial condition is PT. BKDP with a Z-Score of -0.979 in 2018 and -0.600 in 2016. While the company that has the highest Z-Score is PT. TARA with a score of 134,333 in 2018 and PT TARA with a score of 45,637 in 2017.

\section{DEBT}

\begin{tabular}{rrrrrr}
\hline & & Frequency & Percent & Valid Percent & Cumulative Percent \\
\hline \multirow{3}{*}{ Valid } & 0 & 156 & 91,2 & 91,2 & 91,2 \\
\cline { 2 - 6 } & 1 & 15 & 8,8 & 8,8 & 100,0 \\
\cline { 2 - 6 } & Total & 171 & 100,0 & 100,0 & \\
\hline
\end{tabular}

Figure 3. Default Debt frequency

Based on table 3, it is known that in this study the sample companies that did not experience a debt default were $91.2 \%$ with a total of 156 companies, while the sample companies that experienced a debt default were $8.8 \%$ with 15 companies. It can be concluded that in this study, most of the property sector companies in the study sample did not experience debt default, which means that the company has the ability to pay its obligations .

\section{OAGC}

\begin{tabular}{rrrrrr}
\hline & & Frequency & Percent & Valid Percent & Cumulative Percent \\
\hline \multirow{3}{*}{ Valid } & 160 & 93,6 & 93,6 & 93,6 \\
\cline { 2 - 6 } & 0 & 11 & 6,4 & 6,4 & 100,0 \\
\cline { 2 - 6 } & Total & 171 & 100,0 & 100,0 & \\
\hline
\end{tabular}

Figure 4. Frequency of Going Concern Audit Opinions

Based on table 4, it is explained that the sample companies that did not accept going concern audit opinion in this study were $93.6 \%$ with 160 companies, while the sample that received going concern audit opinion was $6.4 \%$ with 11 companies. It can be concluded that most of the companies that were the samples of this study did not receive going concern audit opinion more than the companies that received going concern audit opinion .

\subsection{Model Fesibility Test}

The regression model feasibility test was assessed using the Hosmer and Lemeshow's Goodness of Fit Test . If the value of Hosmer and Lemeshow's Goodness of Fit Test statistic is less than 0.05 , then there is a significant difference between the model and the observed value so that the Goodness of Fit Model is not good because the model cannot predict the value of the observation . Conversely, if the value is more than 0.05 , then there is no difference between the model and the data so that the model is said to be good because it fits the data .

\begin{tabular}{lccc}
\hline \multicolumn{4}{c}{ Hosmer and Lemeshow Test } \\
\hline Step & Chi-square & df & Sig. \\
\hline 1 & 2,238 & 8 &, 973 \\
\hline \multicolumn{4}{c}{ Figure 5. Model Feasibilty Test } \\
\hline
\end{tabular}

In table 5, it shows the value of Hosmler and Lemeshow's Golodness of Fit Test is 2.238 and a significant level of 0.973 . The significant level is $0.973>0.05$ so that the model is able to predict the observation data or the model is said to be fit. 


\subsection{Overall Model Test}

The following table is used to determine the significance level of the difference from -2 initial LL with -2 final LL with a significance level of 0.05 .

\begin{tabular}{llrrr}
\hline & & Chi-square & df & \multicolumn{1}{c}{ Sig. } \\
\hline \multirow{3}{*}{ Step 1 } & Step & 53,063 & 3 &, 000 \\
\cline { 2 - 5 } & Block & 53,063 & 3 &, 000 \\
\cline { 2 - 5 } & Model & 53,063 & 3 &, 000 \\
\hline
\end{tabular}

Figure 6. Omnibus Test of Model Coefficients

The results show that the calculated Chi-square value $>$ the Chi-square table value is $53.063>7,814$. The Chisquare table value of 7,841 is obtained from $\mathrm{df}=3$ at a significance of 0.05 . So it can be concluded that the addition of each independent variable, namely financial distress, debt default, and company size can improve the overall model so that the model is feasible to be interpreted.

\subsection{Coefficient Determination Test}

The value of the coefficient of determination in the logistic regression model is indicated by the value of Nagelker's $\mathrm{R}$ Square. The purpose of this test is to assess how much the dependent variable, namely going concern audit opinion, can be explained by the independent variables in the study. Nagelker's R Square value can be interpreted in the following table.

\begin{tabular}{|c|c|c|c|}
\hline \multicolumn{4}{|c|}{ Model Summary } \\
\hline Step & -2 Log likelihood & Cox \& Snell R Square & Nagelkerke R Square \\
\hline 1 & $28,577^{\mathrm{a}}$ & 267 & ,703 \\
\hline
\end{tabular}

\subsection{Classification Table}

The following table provides information on the predictive power of the regression model for predicting goingconcern audit opinion.

\begin{tabular}{|c|c|c|c|c|c|}
\hline & \multirow{3}{*}{\multicolumn{2}{|c|}{ Observed }} & \multicolumn{3}{|c|}{ Predicted } \\
\hline & & & \multicolumn{2}{|c|}{ OAGC } & \multirow{2}{*}{$\begin{array}{c}\text { Percentage } \\
\text { Correct }\end{array}$} \\
\hline & & & 0 & 1 & \\
\hline \multirow{3}{*}{ Step 1} & \multirow{2}{*}{ OAGC } & 0 & 157 & 3 & 98,1 \\
\hline & & 1 & 2 & 9 & 81,8 \\
\hline & \multicolumn{2}{|c|}{ Overall Percentage } & & & 97,1 \\
\hline
\end{tabular}

Figure 8. Classification Table

Table 8 above shows that of the total 160 sample companies that did not receive a going concern audit opinion, there were 3 sample companies that were predicted to be included in the category of receiving a going concern audit opinion. This means that the predictive power of this regression model to predict the probability that the company will not accept going-concern audit opinion is $98.1 \%$.

Table 8 above also shows that of the 11 companies that received going concern audit opinion, only 9 companies were predicted to be included in the category of receiving going concern opinion, while the other 2 companies were predicted to be categorized as not receiving going concern audit opinion. This means that the predictive power of the regression model to predict the possibility of the company receiving a going concern audit opinion is $81.8 \%$. So that the overall correct prediction rate or the prediction accuracy of this regression model is $97.1 \%$.

5.6 Multicollinearity Test

The purpose of the multicolinealrity test is to test whether in the regression model there is a correlation between independent variables. A good regression model should not have a correlation between the independent variables. Correlation matrix is used to test multicollinearity by assessing the correlation between the independent variables

\begin{tabular}{llrrrr}
\hline & & \multicolumn{1}{c}{ OAGC } & \multicolumn{1}{c}{ BANKRUPT } & \multicolumn{1}{c}{ DEBT } & \multicolumn{1}{c}{ SIZE } \\
\hline Pearson & OAGC & 1,000 &, 241 &, 761 &,- 031 \\
\cline { 2 - 6 } \begin{tabular}{l} 
Correlation \\
\cline { 2 - 6 }
\end{tabular} & BANKRUPT &, 241 & 1,000 &, 222 &, 064 \\
\cline { 2 - 6 } & DEBT &, 761 &, 222 & 1,000 &,- 095 \\
\cline { 2 - 6 } & SIZE &,- 031 &, 064 &,- 095 & 1,000 \\
\hline
\end{tabular}

Figure 9. Multicollinearity Correlations Matrix Test

Table 9 shows the test results where there is no correlation coefficient between variables that is greater than 0.9. Therefore, it can be concluded that there is no correlation between independent variables in this study or multicollinearity symptoms do not occur. 


\begin{tabular}{|c|c|c|c|c|c|c|c|c|c|c|c|c|}
\hline \multirow[t]{2}{*}{ Model } & \multicolumn{2}{|c|}{$\begin{array}{l}\text { Unstandardized } \\
\text { Coefficients }\end{array}$} & \multirow{2}{*}{$\frac{\begin{array}{c}\text { Standardized } \\
\text { Coefficients }\end{array}}{\text { Beta }}$} & \multirow[t]{2}{*}{$\mathrm{t}$} & \multirow[t]{2}{*}{ Sig. } & \multicolumn{2}{|c|}{$\begin{array}{c}95.0 \% \text { Confidence } \\
\text { Interval for B }\end{array}$} & \multicolumn{3}{|c|}{ Correlations } & \multicolumn{2}{|c|}{$\begin{array}{l}\text { Collinearity } \\
\text { Statistics }\end{array}$} \\
\hline & B & Std. Error & & & & Lower Bound & Upper Bound & Zero-order & Partial & Part & Tolerance & VIF \\
\hline (Constant) & -.182 & .255 & & -.712 & .478 & -.685 & .322 & & & & & \\
\hline BANKRUPT & .045 & .032 & .072 & 1.410 & .160 & -.018 & .109 & .241 & .108 & .070 & .943 & 1.060 \\
\hline DEBT & .649 & .045 & .749 & 14.572 & .000 & .561 & .737 & .761 & .748 & .725 & .939 & 1.065 \\
\hline SIZE & .014 & .020 & .036 & .708 & .480 & -.025 & .054 & -.031 & .055 & .035 & .983 & 1.017 \\
\hline
\end{tabular}

Figure 10. Multicollinearity Test Correlations Coefficients

Table 10 shows the test hansill that the value range is narrow, namely the financial distress variable from 0.943 to 1.060 , the variable debt default 0.939 to 1.065 , the company size variable from 0.983 to 1.017 . Because the range is narrow, multicollinearity is not detected. The VIF value shows that the financial distress variable, debt default and company size are less than 10 and a tolerance value is more than 0.01 , it can be concluded that there are no multicollinearity symptoms in this research model so that the test results are said to be reliable or reliable.

\subsection{Hypothesis Testing}

Hypothesis testing is done using logistic regression test with binary logistic regression type. Decision making is done based on the Wald Statistic test to test whether or not the influence of the independent variable partially affects the dependent variable. If the Wald statistic $<$ Chi-square table and probability (sig) $>0.05$, it means that partially the independent variable has no significant effect on the dependent variable; On the other hand, if Wald statistic $>$ Chi-square table and probability $(\mathrm{sig})<0.05$, it means that partially the independent variable has a significant effect on the dependent variable .

\begin{tabular}{rlrrrrrr}
\hline & \multicolumn{1}{c}{ B } & S.E. & Wald & df & \multicolumn{1}{c}{ Sig. } & \multicolumn{1}{c}{$\operatorname{Exp(B)}$} \\
\hline \multirow{3}{*}{ Step $1^{\text {a }}$} & & & & & & & \\
\cline { 2 - 8 } & BANKRUPT & 1,331 & 1,046 & 1,618 & 1 &, 203 & 3,785 \\
\cline { 2 - 8 } & DEBT & 6,041 & 1,345 & 20,162 & 1 &, 000 & 420,235 \\
\cline { 2 - 8 } & SIZE & 1,058 &, 989 & 1,143 & 1 &, 285 & 2,880 \\
\hline
\end{tabular}

Figure 11. Variables in the Equation

Hypothesis testing is done by comparing the sig levels with an error rate ( $p$-value) of $0.05(5 \%)$ and comparing the calculated Wald value with the Chi-square table value. Table 11 shows the logistic regression equation in this study is as follows:

$$
\begin{aligned}
& \operatorname{Ln} \frac{G c}{1-G c}=-19,115+6,041 D E B T+1,331 B A N K R U P T+1,058 \text { SIZE } \\
& \text { GC }=\frac{1}{1+e(-19,115+6,041 D E B T+1,331 B A N K R U P T+1,058 \text { SIZE }} ; \text { or } \\
& \operatorname{Ln} \frac{G C}{1-G C}=e^{-19,115+6,041 D E B T+1,331 B A N K R U P T+1,058 \text { SIZE }} \\
& =e^{-19,115} x e^{6,041 D E B T} x e^{1,331 B A N K R U P T} x e^{1,058 S I Z E}
\end{aligned}
$$

The logistic regression equation model above explains that the negative constant value of $-19,115$ and the Exp (B) value of 0,000 means that if the variables of financial distress, debt default, and company size are fixed or constant, then the log of odds or the probability of the company getting an opinion going concern audit will decrease by a factor of $0.000\left(\mathrm{e}^{\wedge}(-19,115)\right)$. So it can be concluded that if all independent variables are fixed or constant, the company tends not to accept going concern audit opinion .

\subsection{Discussion}

The first hypothesis states that financial distress has a significant effect on going-concern audit opinion . The test results show that the variable financial distress as measured by the dummy scale has a positive coefficient of 1.311 
with a significance level greater than the p-value of $0.203<0.05$ with a calculated wald value greater than the Chisquare table value of $1.618 .<3,841$. So it can be concluded that the first hypothesis is rejected or the financial distress variable has no effect on going concern audit opinion .

The results of this study are inconsistent with Amyulianthy (2014), Maryati (2015), Arsana (2018), Diandika (2017), Ibrahim (2014) that financial distress has a positive and significant effect on going concern audit opinion . However, this rejection is in accordance with the research results of Setiadamayanthi (2016) and Verdhyana (2016). In providing a going concern audit opinion, an auditor will of course pay attention to the company's financial condition. Companies that have serious financial problems may not necessarily receive going concern audit opinion. This condition occurs because a company with a bad financial condition, but has a plan to improve the company's operations and the ability to manage finances properly, and is able to present fair financial reports, will not accept going concern audit opinion . Syahputra (2017) states that going concern audit opinion is not issued to companies experiencing financial distress due to a self-fulfilling prophecy that when the auditor provides a going concern opinion, there is a bad news perception from investors. This is reinforced by the signal theory. Therefore the company has an effort to fix its financial problems by selling all company assets which are managed efficiently and experiencing sales growth every year, so that the company has the funds to pay its obligations (Fauziyah, 2015)

The financial distress variable has a coefficient of B of 1.311 and Exp (B) of 3.785, which means that if the other independent variables are constant or constant, the log of odds or the probability of the company receiving going concern audit opinion increases by a factor of $3.785\left(\mathrm{e}^{\wedge}(-1.311)\right)$ for each increase of one unit in financial distress. So it can be concluded that if it is assumed that the other independent variables are constant or constant, then the possibility of companies receiving going concern audit opinion and experiencing financial difficulties is 3.785 times higher than companies that do not experience financial difficulties (healthy companies) .

The second hypothesis states that debt default has a significant effect on going-concern audit opinion . The test results show that the debt default variable as measured by the dummy scale has a positive coefficient of 6.041 with a significance level smaller than the $\mathrm{p}$-value, which is $0.000<0.05$, with a calculated wald value greater than the Chi-square table value of 20.162 $>3.841$. Based on the test results above, it can be concluded that the second hypothesis is accepted or the debt default variable has a significant effect on going concern audit opinion . The results of the analysis show that the direction of the debt default variable regression coefficient in this study is positive which indicates a positive relationship, where the log of odds the company receives going concern audit opinion increases by a factor of 420.235 for each increase in debt default . This shows that the higher the failure of the company in fulfilling its obligations, the higher the possibility of a company receiving a going concern audit opinion

The debt default variable has a coefficient value of 6,041 and Exp (B) of 420,235, which means that if the other independent variables are constant or constant, then the log of odds or the probability of the company receiving going concern audit opinion decreases by a factor of 420,235 $\left(\mathrm{e}^{\wedge} 6,041\right)$ for each increase of one unit in debt default . So it can be concluded that if other independent variables are assumed to be constant or constant, then the possibility of companies with debt default status and receiving going concern audit opinion is 420,235 times higher than companies receiving non debt default status .

Debt default is defined as the failure of a company to fulfill its principal and interest obligations (Susanto, 2009) . Referring to Audit Standard 570 (2013), the failure of a company to meet its debt obligations is one of the factors that are widely used by auditors to assess the viability of the company .

The results of data processing carried out in this study show that most companies that receive going concern audit opinion experience problems in fulfilling their obligations or receiving debt default status . Based on the data, of the 11 financial reports that received going concern audit opinion, 10 of them received debt defajult status. Companies that receive this status include PT. BCIP, PT. BKDP, PT. COWL who received a statement of default by creditors. Besides that, PT. ELTY, PT. MYRX, is deemed unable to fulfill its obligations because in the year of observation these companies did not pay their principal or interest. Companies that are deemed not experiencing debt default but have received a going concern opinion are due to the fact that the company has successfully entered into agreements or negotiations with creditors to extend maturities or change facilities so that they are not considered a default.

This proves that the debt default status received by the company affects the going concern audit opinion . The higher the possibility of a company failing to fulfill its obligations, the higher the probability that a company will receive a going concern audit opinion. These results indicate that if a company receives default status or fails to fulfill its principal and interest obligations at maturity, it can increase the risk of substantial doubt about the prospects for the continuity of a company, then the auditor will provide an audit report with a going concern opinion in the emphasis paragraph .

The results of this study also support the signal theory, namely the default status or failure of the company to fulfill its principal obligations and the interest indicates disruption of the company's financial condition . Therefore, the auditor as an independent third party as the party that bridges the interests of the agent and the 
principal tends to provide a going concern audit opinion to companies with debt default status as a negative signal regarding substantial doubts regarding the viability of a company .

This result is not in line with the research of Susanto (2009) and Azizah \& Anisykurlillah (2014) which concluded that debt default affects the going concern audit opinion because an auditor in assessing a company's going concern ability is not only based on the company's failure to pay its obligations at maturity, but tends to see the overall financial condition. However, the results of this study are in line with the research conducted by Harris \& Merianto (2015) and Kesumojati, Widyastuti, \& Darmansyah (2017) which concluded that the higher the company's inability to fulfill its obligations, the more likely the company will accept going concern audit opinion .

This happens because the failure of a company to fulfill its obligations is a going concern indicator that is widely used by auditors in assessing the company's survival ability .

The third hypothesis states that company size has a significant effect on going-concern audit opinion . The test results show that the variable company size as measured by natural logarithms has a positive coefficient of 1.058 with a significance level greater than the p-value, namely $0.285>0.05$, with a calculated wald value smaller than the chi square table value $1.143<3,84$. Based on this, it can be concluded that the third hypothesis is rejected or the firm size variable has no effect on going concern audit opinion .

The company size variable has a B coefficient of 1.058 and Exp (B) of 2.880, which means that if the other independent variables are constant or constant, then the log of odds or the probability of the company receiving going concern audit opinion drops by a factor of $2.880\left(\mathrm{e}^{\wedge} 1.058\right)$ for each increase. amounting to one unit in company size. So it can be concluded that if it is assumed that other independent variables are constant or constant, then the possibility of a small company receiving a going concern audit opinion is 2.880 times higher than a large company. The test results on the third hypothesis show that even a large company does not interfere with the independence of an auditor when carrying out his duties. The auditor will maintain his professional skepticism when carrying out an audit of a company by continuing to issue or provide a going concern opinion if there is substantial doubt about a company in maintaining its business continuity regardless of the size of the company.

\section{Conclusion}

This study aims to determine the effect of the independent variables, namely financial distress, debt default, and company size on the dependent variable, namely going concern audit opinion . Research using logistic regression shows the results that financial distress has no effect on going concern audit opinion. Finance will not necessarily receive a going concern audit opinion. This condition occurs because a company with a bad financial condition, but has a plan to improve company operations and the ability to manage finances properly, and is able to present fair financial reports, will not accept going concern audit opinion.

Meanwhile, based on the test results, debt default shows a significant effect on going concern audit opinion . These results prove that the higher the inability of the company to fulfill its obligations, the more likely the company will accept going concern audit opinion. This happens because a company that fails to fulfill its obligations indicates that there is substantial doubt about the viability of the company .

The results of research using logistic regression indicate that company size does not affect going-concern audit opinion. This proves that company size does not interfere with the independence of an auditor. Therefore, even though a company is classified as a small company, it will survive for a long time because it has good management and performance so that the company has less potential to get a going concern audit opinion .

In addition, in this study there are also limitations that may affect the results of the study, namely the limited number of research samples because there are several companies that do not provide the data needed for research and the short term is only 3 consecutive years so it is not long enough to see the publishing trend. going concern audit opinion by the auditor. So that for the next research, other variables can theoretically affect the acceptance of going-concern audit opinion, such as liquidity ratios, activity ratios, leverage, profitability, solvency and auditing. Research should also be extended, not only to property companies but to other segment companies, such as the manufacturing segment. Future studies can also use a longer research period, for example 5 - 6 years.

\section{References}

Arens, A. A., Elder, R. J., \& Beasley, M. S. (2015). Auditing \& Jasa Assurance: Pendekatan Terintegrasi, Edisi Kelima, Jakarta: Penerbit Erlangga.

Bendickson, J., Muldoon, J., Liguori, E., \& Davis, P. E. (2016). Agency Theory: The Times, They are A-changin', Management Decision, Volume 54(1), Volume 174-193.

Bursa Efek Indonesia. Laporan Keuangan Tahunan. Diakses 17 Mei 2020, dari https://www.idx.co.id/.

Dan, K., \& Keuangan, N. O. N. (2012). Opini Audit Going concern: Analisis Berdasarkan Faktor Keuangan Dan Non Keuangan. Accounting Analysis Journal, 1(1). https://doi.org/10.15294/aaj.v1i1.492.

Dewi, D. A. N. S., \& Latrini, M. Y. (2018). Pengaruh Financial distress dan Debt default pada Opini Audit Going concern. E-Jurnal Akuntansi, Volume 22, hlm. 1223-1252.

Geiger, M., \& Raghunandan, K. (2002). Auditor Tenure and Audit Quality. Auditing. A Journal of Practice and 
Theory, Volume 21, pp. 187-196.

Ghozali, I. (2018). Aplikasi Analisis Multivariate dengan Program IBM SPSS, Semarang: Badan Penerbit Universitas Diponegoro.

Harris, R., \& Merianto, W. (2015). Pengaruh Debt default, Disclosure, Opini Audit Tahun Sebelumnya, Ukuran Perusahaan, Dan Opinion Shopping Terhadap Penerimaan Opini Audit Going concern, Diponegoro Journal Of Accounting, 4(3), hlm. 1-11.

Hartono, D., \& Dewi, C. N. (2018). Determinan Penerimaan Opini Going concern pada Perusahaan Manufaktur yang Terdaftar di Bursa Efek Indonesia. Jrak, Volume 14, hlm. 83-94.

Ikatan Akuntan Indonesia. (2015). Pernyataan Standar Akuntansi Keuangan. Jakarta: Salemba Empat.

Institut Akuntan Publik Indonesia. (2013). Standar Audit 200. Diakses 2 Februari 2020, dari https://iapi.or.id/Iapi/detail/362

Institut Akuntan Publik Indonesia. (2013). Standar Audit 570. Diakses 2 Februari 2020, dari https://iapi.or.id/Iapi/detail/362

Institut Akuntan Publik Indonesia. (2013). Standar Audit 700. Diakses 2 Februari 2020, dari https://iapi.or.id/Iapi/detail/362

Kementrian Keuangan RI. (2008). Peraturan Menteri Keuangan Indonesia Nomor 17/PMK.01/2008 tentang Jasa Akuntan Publik.

Kartika, A., Studi, P., Universitas, A., Kendeng, S. J., Bendan, V., \& Semarang, N. (2012). pengaruh kondisi keuangan dan non keuangan terhadap penerimaan opini going concern pada perusahaan manufaktur di BEI. $1(1), 25-40$.

Kesumojati, S. C. I., Widyastuti, T., \& Darmansyah. (2017). pengaruh kualitas audit, financial distress, debt default terhadap penerimaan opini audit going concern E-ISSN 2502-4159. Jurnal Ilmiah Akuntansi Fakultas Ekonomi, 3(1), 62-76.

Kurnia, P., \& Mella, N. F. (2018). Opini Audit Going concern: Kajian Berdasarkan Kualitas Audit, Kondisi Keuangan, Audit Tenure, Ukuran Perusahaan, Pertumbuhan Perusahaan dan Opini Audit Tahun Sebelumnya pada Perusahaan yang Mengalami Financial distress pada Perusahaan Manufaktur ( Stu. Jurnal Riset Akuntansi Dan Keuangan, 6(1), 105-122.

Mada, B. E., \& Laksito, H. (2013). Pengaruh Mekanisme Corporate Governance, Reputasi Kap, Debt default Dan Financial distress Terhadap Penerimaan Opini Audit Going concern, Diponegoro Journal Of Accounting, Volume 2(4), hlm. 1-14.

Mariana, G., Kuncoro, M. D. P., \& Ryando. (2018). Pengaruh Debt default, Disclosure Level, dan Audit Lag Terhadap Opini Audit Going concern (Studi Empiris Pada Perusahaan Manufaktur Yang Terdaftar Di BEI Periode 2009-2013). Seminar Nasional Cendekiawan, (2008), 1043-1053.

Platt, H. D., \& Piatt, M. B. (2002). Predicting corporate financial distress: Reflections on choice-based sample bias. Journal of Economics and Finance, 26(2), 184-199.

Praptitorini, M. D., \& Januarti, I. (2011). Analisis Pengaruh Kualitas Audit, Debt default Dan Opinion Shopping Terhadap Penerimaan Opini Going concern. Jurnal Akuntansi Dan Keuangan Indonesia, 8(1), 78-93 